\title{
Scientific Objectivity: How is it Possible?
}

\author{
Kamen Lozev \\ ORCID: 00oo-0oo1-7272-5690 • ResearcherID: E-7692-2014 \\ South-West University “Neofit Rilski”, Faculty of Philosophy, Blagoevgrad
}

Received 18 November 2017 • Revised 30 November 2017 • Accepted 12 December 2017

\section{Abstract}

\begin{abstract}
The paper discusses the topic of scientific objectivity and how it can be achieved by revealing the views of both leading 20-th century thinkers - Max Weber and Sir Karl Popper. Weber's conception of 'value-free science' is discussed in the first part of the paper. My argument here is put forward according to which the conditions in Germany after WWI and the tendency to politicization of the 'German science' served as one of the reasons why Weber concerned himself with investigating scientific objectivity, both in scientific research and in teaching science in universities. The second part reveals Karl Popper's ideas on the topic of objectivity in science with special emphasis on scientific criticism and rational discussion as the basis of Popper's solution of the problem. Comparisons between the 'Weberian' and the 'Popperian' conceptions of scientific objectivity are drawn.
\end{abstract}

Keywords: Max Weber, Karl Popper, scientific objectivity, value-free science, intellectual honesty, scientific criticism.

\author{
Because for a person as person \\ nothing done without passion has any value. \\ Max Weber (Weber 2000: 121)
}

Wertfrei Wissenschaft (value-free science) is undoubtedly one of the most characteristic phrases forged by Weber to name a doctrine that will always be associated with his name. This is so not because the phrase is so original, nor is it because nobody before Weber ever discussed this topic. The reason is rather because he elaborated Wertfrei Wissenschaft in the rich context of his own achievements. At the end of his life Weber edited and published two important works - Science As a Vocation and Politics As a Vocation. It is known that they originated as a result of editing two lectures given before students in 1919 (Daskalov, 2000: 146). The sociopolitical context in which these lectures were published is very interesting and probably contains the reasons why Weber decided, at this moment, to set forth more systematically his views on science and politics.

For Germany the first years after the Great war were turbulent. During 1919, within a few months, the Germans were presented with both - the unjust Versailles Treaty and the Weimar Republic with its Constitution (Weber was involved in its creation). The country slipped into economic and political chaos. Encouraged and supported by Moscow, the German communists undertook an unsuccessful attempt for a revolution. At the end of the war Weber, who uncompromisingly and harshly condemned any attempt for political changes through (C) Authors. Terms and conditions of Creative Commons Attribution 4.0 International (CC BY 4.0) apply. Correspondence: Kamen Lozev, South-West University "Neofit Rilski", Faculty of Philosophy, 66 Ivan Michailov st., 2700 Blagoevgrad, Bulgaria. E-mail: kamenlozev@abv.bg. 
revolutionary means, also undertook an unsuccessful attempt to engage himself with real politics. Soon, however, filled both with disappointment and new inspiration for work, he returned to the bosom of research and teaching: he lectured a few months at the University of Vienna and then settled in Munich as Director of the first Sociological Institute in Germany. In mid-June 1920, here in Munich, while passionately devoted to his last and most significant works, Weber unexpectedly died of pneumonia at the age of fifty-six (Mityurin, 2006: 23).

The disenchantment of the world through science continues. Raymond Aron

(Aron, 2000: 12)

The theme of science, conceived both as vocation and profession, but also as a component of the huge uncontainable process of intellectualization of society and disenchantment of the world, going on in the latter half and the early twentieth century, has its relevance even today and will hardly ever lose its importance soon. In essence, the social realities analyzed by Weber have not much changed and therefore his conclusions, expressed in a clear and accurate language, still serve as a guide and still inspire and educate generations of social thinkers.

For Weber the topic of science comes to the fore not just in this professional and research context, i.e. it was not simply an unavoidable topic of his sociological and economic studies of modern society. For him, science is a deeply personal theme, biographically 'written' into his life trajectory (Daskalov, 2000: 146). Science and politics - for the young Weber both akin as opportunities and vocation - have long been in competition as to which one should earn his efforts. To which god he should devote his talents and life - for the young Weber this has been a battle without winner for years (Kim, 2012). From today's perspective we can, with some satisfaction, 'thank' Weber that, both professionally and as a vocation, he gave preference to science over politics and thus, albeit indirectly, even if through theoretical illumination of politics as an activity, he managed to balance in himself both callings, tame the elements and reconcile the gods in his chest. Weber took a sober view and judged that the achievements of the spirit are much more solid and lasting than those of a politician of whatever rank. Moreover, when he was in his prime, Germany hardly ever needed a politician-intellectual like him. This claim was twice as true applied to revolutionary Germany after World War I when Science as a Vocation came out.

$* * *$

In what follows bellow I limit myself to a few key points on the subject of scientific objectivity (value-free science) as presented by Weber together with a brief sketch of Karl Popper's understanding of the subject, viewed primarily as a search for objective knowledge or "valueneutral" science. The emergence of the value issues in science can probably be logically inferred from the general course of Weber's research. Yet the Introduction of Raymond Aron (2000) suggested a conjecture, which I think was significant for Weber and deserves our attention. I guess that Weber - though undoubtedly a patriot and a nationalist (initially a fervent nationalist who, like all intellectuals at the time, supported the war, but then evolved into one of the severe critics of Kaiser Wilhelm, demanding democratization of his authoritarian regime, constitutional reform with strong Parliament and universal suffrage, Kim, 2012) - had anticipated a tendency that shortly after his death, and especially in Hitler's Germany, developed to the shameful size of painful politicization of science, a phenomenon which with full force, and in parallel, was ongoing in the USSR and which is a very important component of the theme of the value-laden science. 
We came to know the "Aryan mathematics", we know today a state that settles the scientific dispute on inheritance of acquired traits or the theory of Mendel. Ultimately, I do not think there were many German mathematicians who took seriously the difference between the "Aryan mathematics" and the "Jewish mathematics", nor do I think that many physicists thought Einstein was rejected due to his race or his religion. But it was tough in a country like Germany so many scientists to be forced to silently tolerate this unworthy comedy, as if they were taking it seriously...

Raymond Aron (Aron, 2000: 13)

The important themes in the works of Weber - the disenchantment of the world, the rationalization of society, the intellectualization of production, etc. - all suggest the awareness of the importance of science and the close inspection of its functions in different social spheres. Weber had diligently studied and summarized all this. If we add to his theoretical achievements the experience he gained by teaching at various German universities, we shall get the portrait of the adequate and skilled analyst of the value issues in science.

In his lecture Science as a Vocation Weber discussed mainly the social and economic science, but many of his generalizations refer to all sciences, and as for the issues on teaching science in universities, his conclusions, I think, are indisputable even today.

It is very likely that the greatest incentive to choose exactly this specific topic for the lecture before the students, as well as the important points in it - namely, the impartial teaching of science, the personality of the lecturer, the fate of the person devoted to science - came from the realities of the war. Under the wartime conditions, especially during the chaotic time of 191819 , one can hardly imagine that university professors in Germany would remain impartial while lecturing, that they would never "weave" their own thoughts and feelings into the way they teach their subjects, that they would not express their agitation of soul and bias at a time when the nation is at a crossroad. Under these circumstances it is hardly ever possible to be in line with the objectivity and the required distance from "what is happening in the outside world", on which Weber insisted vis-a-vis the teaching process. Weber must have witnessed not just the violation of the norms of "intellectual honesty", but also many shameful and reaching the extreme scenes. To some of them he only hints, but we should hardly doubt that he was well aware of the unleashing of the shouvinization and politicization of the "German science" during the first months of the war. In August 1914, after literally hitting Belgium, the Germans burned the Library of the Catholic University of Leuven, and to the protest of the British scientists that this was an act of vandalism the German scientists responded with a precise "cleaning" of all German scientific books and the entire "German science" of the "unnecessary English terminology". This tendency was particularly strong in the field of physics and mathematics, but it also affected other sciences such as medicine. During the 1920-s, with the rise of National Socialism, this tendency grew in breadth only to acquire its real face in the thirties, when the "pure" "German" or "Aryan" science was formed taught only by Aryan scientists and using only textbooks that were clean of "Jewish theories" and contained no names of Jewish scholars.

With its sharp and sympathetic sociological insight Weber, the acclaimed member of the academic community of Germany and one of its glorious names of international renown, had undoubtedly closely observed this process. So most likely the topic of the impartial lecturer who should teach knowledge and methods, and not preach ex cathedra behind the desk as if it were a 
pulpit to raise champions of causes alien to science, naturally occurred in the form of "value-free" science. I will hardly go wrong if I claim that this was Weber's personal reaction to the perceived and increasingly becoming more and more clear tendency towards the "German science", completely dominated by party-political values.

Science as a Vocation was Weber's decisive rebuff to this process, then still in its infancy. The lecture makes me see Weber among those who, like Heisenberg, would prefer to be called "white Jews" than to deny "the Jewish achievements" in science like Einstein's Theory of relativity or the Quantum mechanics of Niels Bohr. It is well known, that the "Aryan science" struck a heavy blow to the culture of Germany and underlay the lagging behind and backwardness of the German scientific technical and engineering thought during the war and for some time afterwards.

Today it is often spoken about a premises-free science? Does it really exist? Max Weber (Weber, 2000: 130)

Weber's thesis of value-free science should not be one-sidedly understood. In fact to argue that there are no values in science is exactly the opposite of what his lecture suggested to the student audience. Weber himself unequivocally states that "science is not premises-free" (Weber, 2000: 142), which means that it is based on certain values.

The presence of values in science is not just beyond doubt and needless to discuss. It is a claim from which one is to move forward, it does not require justification. Weber is a faithful follower of Kant and shares his distinction between theoretical and practical reason, between the Hume's spheres of is and ought. He is also an enthusiastic reader of Nietzsche with his "perspectivism" according to which every point of view is inevitably imbued with bias, assumptions, values (Ringer, 2004: 148).

Therefore, it would be naive to expect that Weber would neglect, much less not understand, the role of values in science. Until 1919 he had conducted numerous sociological and economic analyses of various issues which have revealed the presence of value orientations, and have highlighted the ways in which values function in a study. "The selection of facts", Raymond Aron (2000: 7) writes: "The elaboration of concepts, the defining of the subject, Max Weber said, are marked by the orientation of our interest. Natural sciences select from the infinity of the sense given the phenomena capable of repetition, and then construct the edifice of the laws". The values are our "mental eyes", through them we choose and arrange the facts. Value is of a higher order compared to whatever particular scientific claim, conclusion or result.

Weber's position is a position of strict and clear distinction of facts, on the one side, factual judgments respectively, and values, on the other, respectively value judgments. Values are above facts. And if it is true that science deals with facts, which it examines, collates, analyzes, etc. in order to create theories which in a specific language describe and explain them, the same does not at all apply to values. On the contrary, according to Weber we can definitively say the following about them: no science can ever justify them. They can be justified neither by the object of the investigation, nor by any underlying basis of their own (Hoenisch, 2006).

Values are subjective in nature, they are a matter of faith, of subjective disposition, just like the gods in which we believe. That is why Weber often speaks of the "gods", who argue and fight in our souls and hearts. Having in mind Weber's understanding of values Hoenisch (2006) writes: "The ultimate values are subjectively defined. The intimate value is by definition personal, it is an opinion. It has the connotation of emotion, mystification". 
Science is applicable to facts but not to values. Application of scientific method to attain knowledge of values is irrelevant. Values inhabit a sphere totally different from the one of facts and this is why science is never able to make them its object. This position, in one form or another, Weber repeatedly conveys to his young audience. "How could we", he asks rhetorically, "'scientifically' make a choice between the value of the French and the German culture - this I do not know. Here different gods argue - and they argue forever" (Weber, 2000: 136). And a little later in the same context: "Who would dare 'scientifically' to refute the ethics of the Sermon on the Mount, for example the principle 'do not resist evil' or the metaphor of the one and the other side?" (Weber, 2000: 136).

Where faith and emotions are involved, which is exactly the case with values, it is pointless to cherish hopes for support and assistance from any intellectual, rational, "scientific" means. For example, we should not think that value conflicts or disputes over values can "rationally" be resolved by arguments. In the world of values there are no order and priorities, there is no reflection on the "subject of study", no logical thinking here can ever be an authority. The presence of values should be taken as a postulate without discussion - such are the conclusions of Weber.

But from the fact that with the methods of science values cannot be investigated, that they are beyond the scope of science, it does not follow that values are "invisible", "elusive" or "unclear". On the contrary, according to Weber, each researcher must exert efforts and constantly clarify his own "perspective", his own "point of view", the value or the group of values that guide his research. Weber's concept of "intellectual honesty" boils down exactly to this point - the requirement to clarify yourself your own "gods" and loudly to announce them.

Where do values come from? How and why do they come into existence? Such issues Weber does not discuss in detail. His position logically excludes them as not essential. The value orientations of the social scientist may be a result of shared wider social norms, of Weltanschauung, religion or nationality; their source may even seem to us eccentric. All this is of no importance. What is of importance, according to Weber, are two things: first, the social scientist should be well aware of the values which guide his own research, and honestly share them; and secondly, once adopted, the value must be upheld and followed. A conviction that is left "to be downloaded from the saddle", is not true, Weber writes (cit. in Daskalov, 2000: 174). Therefore, the scientist who does not adhere firmly and decisively to the deepest value basis of his work, who exhibits hesitation and frequent change of the perspective, does not fulfill the requirement of intellectual honesty. Moreover, he hardly stands up to the idea of a scientist, namely, of someone who has chosen science as a "vocation".

$* * *$

For Weber the value clashes, the passionate defense of values chosen and pursued is of great importance. There is no doubt that it is in this dynamics of accepted, advocated and abandoned values where the enormous power of science is hidden. This is its principle of eternal revitalization, this is what fundamentally distinguishes science from dogmatized ideologies or religions. We can speculate in broader terms that Weber probably saw it as an advantage the fact that "scientifically" values can never receive final justification, legitimisation or "proof". If it were not so, then it would not be excluded to witness some sort of cultural stagnation. On the contrary, the tensions between ever competing values are essential and healthy for society and that is why Weber insists on their defence and protection to the full.

Weber speaks with the same force and conviction about the values in the auditorium, that is, in the process of teaching. In his time the reality in Germany was such that scientists did both research and lecturing. It is true that both skills - for research and for teaching - do not 
always coincide. However, it is always the case that "when it is said of an associate professor that he is a bad lecturer, for him this is an academic death sentence, even if he were the first researcher in the world" (Weber, 2000: 119).

With respect to the values, lecturing carries in itself the greatest temptation. Therefore, Weber's requirements here are strict and explicit. During the war, when Germany was possessed by the strong wave of nationalism, Weber cries out for purity and special "hygiene" of the teaching activity. "The task of the lecturer is to be of help to the audience with his knowledge and scientific experience, and not to model them according to his personal political beliefs", Weber insists (2000: 134). It means that the lecturer should adhere only to teaching knowledge and methods.

In his lecture Science as a Vocation Weber explains to the students that the politician will commit mortal sin if he showed signs of estrangement from his cause, or if he grew haughty and became irresponsible. The politician, like the scientist, must put passion into his work for it is an old truth that without passion nothing great is ever achieved. And at this point there seems to be a contradiction - the social scientist, the passionate devotee of his work, in the auditorium must remain cool and impartial; he should teach his "subject" from safe distance, without rubbing the audience with his own "gods". This indeed is a challenge, especially in the social and economic sciences. The temptation to stand at the lectern as a prophet or as a speaker of the truth of last resort, to infect the audience with a certain "mindset" and play the role of its leader, is immense. According to Weber, however, not to resist such temptation, is also a mortal sin.

The reasons for this mortal sin are basically two. First, the prophecy in the auditorium, condemned by Weber as "lectern prophecy", is completely immune to criticism and other challenges. For Weber, the students in the auditorium, like the laity in churches, are doomed to silence (Weber, 2000: 134). This is the most convenient, secure and easy position for the preaching of any "world view". And just because the situation is so easy and convenient to suggesting any ideas, Weber urges his colleagues to chase away the devil, not to succumb to the temptation and not to do this mortal sin: “... because the place of the prophet, and of the demagogue, is not behind the lectern in the auditorium. It is said to the prophet and to the demagogue: 'Go out in the street and speak publicly!' That is, go to a place where criticism is possible” (Weber, 2000: 134).

The second reason is more limited but no less important. It boils down to whether the value of a person depends on whether he possessed the qualities of a leader. Weber's answer to this question is explicitly negative. And yet: what should the teacher do in the case when besides the "calling for science" he sincerely feels the calling to be a "leader" too? According to Weber, "from one hundred professors at least ninety nine do not claim, and should not pretend, to be leaders" (Weber, 2000: 138), and this is so because the auditorium is the last place on earth where the leader's gifts should be proved. As for the only one out of the one hundred teachers, "who feels called upon to intervene in the struggle between worldviews and party opinions", Weber's advice to him is also explicit: "let him do this out in the market of life, in the press, at meetings, in public associations, wherever he desires. But it is not right to show the courage of his faith where those who are present - and who perhaps think differently - are doomed to silence" (Weber, 2000: 138).

$* * *$

Recognition of the value orientation is a prerequisite for objective judgment.

Steve Hoenisch (Hoenisch, 2006)

At the end of his lecture Weber offers his resolution to the problem of value-free science. At first glance such a science is impossible: Weber himself has extensively briefed his student audience with the values of science. Values are by nature subjective, mystical, irrational, 
non-scientific; they are probably the most direct negation of everything the objective scientific spirit, the most important characteristic of science, suggests. And so the question arises: how is it possible to simultaneously hold that values in science cannot be eliminated, that they influence the research process, the selection of facts and their arrangement; and to raise the ideal of independent, value-free science? Is there a way out of this situation? Is there a solution to the problem of "value-free" science? If yes, what is it?

Weber's answer is positive and optimistic. According to this answer escape from the subjective values in science is impossible: we have to recognize them with all their importance in the research process. But that recognition is exactly the important part of the solution. The experts on Weber unanimously agree that he accepts the subjectivity, the inevitable presence and the importance of the values in science, on the one hand, but also the possibility for objective analysis and assessment of the actions of both the politician and the scientist, on the other. This position is expressed in a number of works.

According to Weber the value-determined point of view of the social scientist is not only permissible; it can not be eliminated in social science. Between the lack of values and ideals in science and the scientific objectivity there is no close proximity. It would be an illusion to construct the notion of "pure science" in the sense of science without values. On the contrary, freedom from values does not mean absolute rejection of values but becoming aware of them and clarifying them. From this perspective, analysis and evaluation, knowledge and values are not sharply opposed; they are rather closely interlinked and mutually suggest each other. There cannot be objectivity in science or objective analysis of the facts without well clarified, value-laden, perspective of the scientist. If the latter were not fulfilled no distancing and no objective assessment of the activity would ever be possible (Ringer, 2004: 3).

Weber strongly emphasized on understanding this situation. It separates the subjectivity of the value orientation from the scientific objectivity which can be achieved only after the value orientation is clarified. If the social scientist fails to clarify, or what is worse - if he is not aware of the value basis of his own perspective - we cannot expect that he will display impartiality and objectivity in science. There is no objective analysis carried out from an "independent" viewpoint. The principle of objectivity is possible only after we clearly engage with certain goals and values. Thus objectivity in science is not absolute but conditional, it is rather $a$ posteriori than a priori; it is possible only after the choice of certain values and perspective has been made.

Weber emphasizes this point: the subjective values set the starting point in science, but from here on its way forward is objective and therefore can be objectively assessed. Weber criticizes the scholars who allow the subjectivity of their perspective to be manifestly felt in the analysis of the facts. By way of examples he indicated the historical apologists and the Marxists (Hoenisch, 2006). Led by their subjective values, they become their slaves, without adhering to the ideal of objectivity. In his lecture on science Weber admits that for him what the key values of a politician or a scientist are is even less important than whether he clarifies them for the benefit of both himself and his audience.

The 'freedom from values' in science understood in this Weberian sense relates to the conception of objective judgment. The point here is that when the scientist, or the politician, has determined his values and objectives, when he pledged his honour to his "deity", this allows us to judge rationally, "objectively" (for Weber "scientifically") as to how adequate or inadequate the means and methods of the politician or the scientist are when applied to achieve the goals set in advance. In other words, when the values and goals are clarified, communicated and defended, the scientist or the politician progress in their work in an objective, value-free way. Thus it becomes possible to reconstruct and evaluate "objectively" their actions. 
There is a difficulty here, or rather a "temptation", to which Weber did not turn a blind eye. Usually, when the relation "means-purposes" enters the discussion, it is always the case that the moral question is raised as to can the purpose justify the means. In the context of science the problem assumes the form: is it possible "scientifically" to justify the means for attaining a certain goal? In his lecture Weber answers this question and the answer is definitely negative. Science cannot provide moral support for applying specific means to achieve certain goals. However, with scientific means, we are able to assess whether, given the particular purpose, the appropriate tools and methods to achieve it are used or not.

According to Weber, the mission of the teacher is this: to provide clarity and understanding of the choices we inevitably face in science and in politics. Weber tells the students: "... we could clarify to you that on the issue of values we are discussing now ... one can take such and such practical positions. If you took this or that position, then, according to the experience of science, you should implement such and such means to carry it out in practice. Maybe these means themselves are such that you feel it necessary to reject them. Then you must choose between the purpose and the inevitable means" (Weber, 2000: 139). In other words, your decision to serve one "god" or another, to share one worldview position or another necessarily implies to walk on "this" rather than on "that" road, to use "these" and not "those" means, to expect exactly "these" and not "those" consequences. All that science can reveal, and it is in this respect that it can guide you. We should not expect of science to set the purpose of human life or to decide how to live with dignity; however, under already set goals, science is able to illuminate the future.

Is this enough? Weber anticipates the disappointment of a large part of the audience, but the good, intellectually honest lecturer should not exceed those limits. His calling is to encourage or help the individual "to realize the deepest sense of his own actions. This does not seem to me to be so small even for the private life. And I am tempted to say here that if a teacher succeeds in this, he serves a 'moral' force - to create duty, clarity and a sense of responsibility and I believe he would be the more capable of such achievement, the more consciously he avoided imposing or suggesting views on the listener" (Weber, 2000: 140).

$* * *$

If we should briefly summarize Weber's notion of value-free science, we should pay attention to two main points. The first one concerns the dichotomy facts-values, and, consequently, the worlds of is and ought, separated by a gap. In the early twentieth century this doctrine, which came from Hume and Kant, clearly set out in Wittgenstein's Tractatus Logico Philosophicus and enthusiastically adopted by the Vienna Circle, dominated European philosophical thought. This doctrine Weber fully shares; his proposed solution to the problem of value-free science is based on it.

The second point refers to the focus on the individual scientist, respectively politician. There is no doubt that Weber sought, and ultimately found, the solution of the scientific objectivity issue in the personality of the scientist. Weber believes, like many others, that the formation of the scientist, the orientation of his mind to his duty and intellectual honesty, to scientific impartiality and distancing from the object of study, the careful and thorough analysis of the facts, the elimination of subjective sympathies and bias in the selection and assessment of facts, the recognition of facts inconvenient to one's own position and serving only to the scientific truth, etc. is the path to go to achieve value-free science. Is science itself in any way related to this solution? According to Weber - no: "Of course, scientifically, we cannot show anyone what his duty as an academic teacher is. We could require of him only intellectual honesty - to understand that ..." (author italics - K.L.) (Weber, 2000: 133). 
As we see, Weber focuses on the requirements: the clear and precise requirements to the lecturer, respectively the researcher - this for him is the solution. True, the requirements are formulated in terms of ethical duty and the moral standards of honesty, impartiality, etc., but put firmly and resolutely forward, they should lead to the solution. We may take this to be the "German" way or the "German solution" to the problem raised by Weber. It is well known that he was a Kantian and obviously believed that the demands of the Categorical Imperative, the moral duty, the stringent requirements and clear message to the scientists is what is really needed. It can hardly be doubted that this strong conviction was in fact the deep motive for Weber to give his lectures and write on these issues - he believed in the explanatory, "enlightening" function of his works that will guide everyone who has chosen science as their vocation.

$* * *$

The ideal scientist is not the objective and "value-free" scientist. Karl Popper (Popper, 2003a: 89)

... objectivity is based solely on criticism. Karl Popper (Popper, 2003a: 88)

Popper has left us evidence that he is very well acquainted with the ideas of Weber, whom he revered as one of the greatest minds of Germany, calling him a "great social scientist". Although Popper sometimes refers to Weber and uses his terminology, he does not specifically deal with him. However, judging from the nature of Popper's view of scientific objectivity, there is no doubt that Weber's solution of the value-free science issue would inevitably fall within the scope of Popper's criticism.

The father of Critical rationalism vigorously opposes any notion of objectivity in science, closed on, or fixed on the consciousness of the individual scientist, on the requirements (especially the moral requirements) to him. Popper, like Weber, believes in the power of scientist's passion as well as the role played by scientist's obsession with his work. That is why Popper is very skeptical that the latter can be overcome by "clarifying" of scientist's duty or through appeals for honesty and impartiality in research.

Weber and Popper were very different as thinkers. The former is committed to the social and economic sciences, while the latter, although he left important works in the field of social and political philosophy, is best known for his ideas in the field of methodology and philosophy of science (Lozev, 2000: 13). Unlike Popper, Weber is not closely familiarized with the problems of natural science and this, as we can expect, determines the existence of differences between them.

On the issue of value-free science, however, they both shared many common views. For example they both understood the great importance of values in scientific work: in the process of the selection and arrangement of facts, in the formation of certain research attitude, etc. In addition, both Weber and Popper distinguished between facts and values: they both agreed that unlike the facts which the scientific theories try to explain, values cannot be the subject of study with the ordinary tools of science.

However, regarding the key issue - How do we achieve objectivity in science? - Weber and Popper held different views. Objectivity in science, according to Weber, is attained as a result of certain rules and principles, observed both in the research process and while teaching of science in the auditorium. They are specified in the relevant requirements to the scientist and when not adhered to, consciously or unconsciously, the result is non-objectivity of science. What regulates the adherence to the requirements by the scientist? The following quote clearly reveals the thinking of Weber in this case: "Of course, it is possible that the lecturer does not succeed to 
eliminate his subjective sympathies to the sufficient extent. Then he exposes himself to the most severe criticism before the forum of his own conscience" (Weber, 2000: 134).

Popper by no means accepts Weber's solution of the objectivity problem in science, much less does he agree with science's "regulator". For him, the forum of one's own conscience, with its subjective nature, is in principle irrelevant to science, just like the subjective conviction has no relevance to scientific objectivity. In Chapter Eight, Part Two, of his first work The logic of scientific discovery (1934, 1959), entitled "Scientific objectivity and subjective conviction", he states: "... the subjective experience or the sense of conviction can never justify a scientific statement ... No matter how strong the sense of conviction is it does not justify a scientific statement. ... Can any statement be justified by the fact that K. R. P. (Karl Raimund Popper) is fully convinced of its truth? The answer is 'No' and any other response would be incompatible with the idea of scientific objectivity" (Popper, 2002: 23-24).

$* * *$

Unlike Weber, who believes that the well understood duty is able to eradicate bias and everything that impedes scientific objectivity, Popper is distrustful and suspicious of the scientist. He knows that "it is totally wrong to think that the attitude of the natural scientist is more objective than that of the social scientist" and that the natural scientist is "extremely addicted to promoting his own ideas in a unilateral and party-like way... Some of the greatest physicists even founded schools that raise strong barriers to new ideas" (Popper, 2003a: 87). According to Popper we can never eliminate scientist's personal bias, the passion that leads him in his research, "nor can we ever ban or destroy his value judgments, without destroying him at the same time as a human being and as a scientist" (Popper, 2003a: 89).

Therefore, concludes ultimately Popper, scientific objectivity must be sought elsewhere, outside the motives and personal impartiality, outside the open-mindedness and the 'objectivity' of the individual scientist. And Popper finds the solution in what he calls the public nature of the scientific method (Popper, 1995: 236). The poperian solution of value-free science in essence was outlined in 1934, but in a more elaborate and systematic way is was presented in the second volume of The Open Society and Its Enemies (chapters 23 and 24, where the sociology of knowledge was criticized) and in some later works.

To understand Popper's view of scientific objectivity we should trace back his interpretation of the theme in historical aspect, starting from the classical empiricists, Hume included, through Kant and Hegel and reaching the sociology of knowledge in the face of Max Scheler and Karl Mannheim whom he criticized.

In an attempt to explain the sources of error in the cognitive process the empiricists explored the "material" delivered to the mind by the senses. According to them the elements of this "material" arouse associations responsible for the mistakes we make. The empiricists identified the solution of their problem in the elimination of the factors that affect cognition, namely, in achieving knowledge-without-prerequisites. How? By adhering to complete passivity in the cognitive process, with "ready for perception senses" (Popper, 1995: 232).

Kant rejected this pacifist theory of knowledge, insisting that the acquisition of knowledge implies active engagement with searching, comparison, unification, generalization. Freedom-of-any-prerequisites in the cognitive process, according to him, is impossible. The subject enters the cognitive process intellectually equipped with a categorical apparatus which forms the structure of our human reason. And since the categorical apparatus for Kant is unified, true and immutable (Popper, 1995: 232), we can acknowledge in it the solution of the problem related to objectivity in science. 
According to Popper through the unity of human reason Kant seeks to justify the unity of humankind, while Hegel through emphasizing the dependence of human intellectual abilities on the social heritage and the social environment, and, ultimately, on the development of the society and the nation to which a person belongs, created "the doctrine that all knowledge and all truth is 'relative' in the sense that they are determined by history" (Popper, 1995: 233).

Popper is confident that it is Hegel's ideas which gave birth to the sociology of knowledge - a teaching which "proceeds from the assumption that scientific thought, and especially the thought on social and political issues, does not originate in a vacuum but in a socially conditioned atmosphere" (Popper, 1995: 231). The social environment produces a whole system of views and theories hidden for the subject of thought which he takes for granted as unquestionably true, obvious, trivial truths. They form a group of socially determined conditions that sociologists of knowledge called total ideology (Popper, 1995: 231).

In this picture of knowledge which, according to Popper, is simply a repetition of Hegel's ideas in more recent times, scientific objectivity can be achieved by revealing, unveiling of the total ideologies, that is, the hidden motives and guiding determinants of scientific thinking. To achieve this goal we have to undergo a kind of psychotherapy or sociotherapy - procedures, which place the sociology of knowledge next to psychoanalysis (Popper, 1995: 233).

Popper's brief historical excursion suggests that the above teachings view the cognitive process or science as taking place in the mind, in the consciousness of the individual scientist. As is the case with Weber, this is their Achilles heel. "If scientific objectivity, so naively conceived by the sociological theory of knowledge", Popper wrote, "is based on the impartiality or the objectivity of the individual scientist, then we should say goodbye to it” (Popper, 1995: 235).

$* * *$

The so-called objectivity of science lies in the objectivity of the critical method; i.e. primarily in the fact that no theory is excluded from criticism, and also in the fact that the logical instrument of criticism the logical contradiction - is objective.

Karl Popper (Popper, 2003a: 82)

In 1934 Popper comprehends scientific objectivity as inter-subjective test, but in 1945 he expanded this concept to the social aspects (or the inter-subjectivity) of the scientific method (Popper, 1995: 236).

This view is based on two main instances: the first one is the public nature of the scientific method, which finds expression mainly in the freedom of criticism. In science there are no authorities; on the contrary, according to Popper scientific thinking "means criticism of everything" (Popper, 1995: 236). The second point is the fact that in science (Popper spoke mainly of natural science, although much of his conclusions apply to social and economic sciences) experience is the impartial arbiter of disputes. Here "experience" boils down to mainly observations and experiments. Experiment is "public" if "everyone who wants and makes efforts can repeat it. To avoid misunderstandings in scientific discussions, scientists are trying to formulate their theories in such a form that they can be checked, i.e. refuted (or supported) by social or public experience" (Popper, 1995: 237).

So Popper's view turns around the logic of the teachings criticized by him - objectivity in science is not the result of the individual efforts of the scientist to be impartial; it is rather the result of the very scientific method. It is the method itself, as the embodiment of the social and 
institutionally organized objectivity of science, which "forces" the scientist to be impartial and unbiased.

Popper pays particular attention to the social institutions that enable objectivity in science through perfecting and expanding the opportunities for criticism. Institutes such as scientific periodicals, regularly held congresses and conferences, thematic discussions, etc. - they all encourage and ensure scientific objectivity. In this respect, one of the most important conclusions of Popper states: "Only the political power can impair the functioning of these institutions, on which ultimately all progress depends - scientific, technological and political when that power is used to suppress free criticism or when it fails to protect it" (Popper, 1995: 237).

$* * *$

In the manner of summary of the popperian position on the value-free science we pay attention to the important similarity between Weber and Popper. Although the two theorists hold different views on what regulates and ensures scientific objectivity, they both emphasize the ethical aspect of the issue. At some point they both put their views in ethical terms. In Toleration and Intellectual Responsibility Popper directly stated: "Thus the ethical principles form the basis of science. The idea of truth as a fundamental regulative principle - the principle that guides our search - can be seen as an ethical principle" (Popper, 1995: 217).

Ethical is also the nature of the principles of intellectual honesty and recognition of errors, the maintaining of critical and self-critical attitude and tolerance. Ethical in nature are the fundaments of Critical rationalism, together with the norms of critical discussion. And just like Weber who insists that in the spirit of intellectual honesty we should admit all facts that do not agree with the position we have chosen, Popper insists that in all critical discussions we should appreciate the opponent as a source of new knowledge and especially value the well argumented criticism on his part.

More characteristic of Popper is the direct link he sees between the search for truth and the moral qualities of a person. "I am all for the intellectual courage. We can not be both intellectual cowards and seekers for truth" (Popper, 2003: 195). The true scientist, devoted to science as his vocation, must have the courage to become revolutionary in the field of thought.

A statement which Weber would undoubtedly endorse.

\section{References}

Aron, R. (2000): Aron, R. (2000). Vavedenie, - Veber, M. (2000). Ucheniat i politikut, Sofia: EON, 5-50. (Арон, Р. (2000). Въведение, - В: Вебер, М. (2000). Ученият и политикът, сс. 5-50). [Aron, R. (2000). Introduction. In: Weber, M. (2000). The scientist and the politician. Sofia: EON, pp. 5-50)].

Brubaker, R. (1991). An essay on the social and moral thought of Max Weber (Controversies in sociology). London \& New York: Routledge.

Daskalov, R. (2000): Daskalov, R. (2000). Mejdu nauchnia i politicheskia razum, - V: Veber, M. (2000). Ucheniat i politikut, Sofia: EON, ss. 146-182. (Даскалов, Р. (2000). Между научния и политическия разум, - В: Вебер, М. (2000). Ученият и политикът, сс. 146-182). [Daskalov, R. (2000). Between the Scientific and Political Reason - In: Weber, M. (2000). The scientist and the politician, pp. 146-182.)]. 
Hoenisch, S. (2006). Max Weber's view of objectivity in social science (online). Retrieved on 10 May 2015, at http://www.criticism.com/md/weber1.html

Kim, Sung Ho (2012). "Max Weber”, The Stanford Encyclopedia of Philosophy (Fall 2012 Edition), Edward N. Zalta (ed.), at http://plato.stanford.edu/archives/fall2012/entries/weber / .

Lozev, K. (2000): Lozev, K. (2000). Sotsialnata filosofia na Karl Popar. Sofia: KALUS (Лозев, К. (2000). Социалната философия на Карл Попър. С.: КАЛЬС). [Lozev, К. (2000). The social philosophy of Karl Popper, S.: KALAS)].

Mityurin, D. (2006): (in Russian) Veber, M. (2006). Maks Veber za 90 minut, Moskva: Sova, ACT (Митюрин, Д. (2006). Макс Вебер за 9о минут, М.: Сова, АСТ). [Mityurin, D. (2006). Max Weber for 90 minutes. M .: Sova, ACT)].

Popper, K. (2002). The logic of scientific discovery. London and New York: Routledge.

Popper, K. (1995): Popar, K. (1995). Otvorenoto obshtestvo $i$ negovite vragove (Dpogeyat na prorochestvoto: Hegel, Marks i posleditsite), tom 2, prev. K. Lozev, S.: Fondatsia 'Otvoreno obshtestvo - Sofia' i Zlatorog. (Попър, К. (1995). Отвореното общество и неговите врагове (Апогеят на пророчеството: Хегел, Маркс и последиците), том 2, прев. К. Лозев, С.: Фондация „Отворено общество - София” и Златорогъ). [Popper, К. (1995). The Open Society and its Enemies (The High Tide of Prophecy: Hegel, Marx and the Aftermath), Volume 2, transl. by K. Lozev, Sofia: "Open Society - Sofia" and Zlatorog)].

Popper, K. (2003a): Popar, K. Logikata na sotsialnite nauki, - V: Popar, K. (2003). V tarsene na po-dobar sviat. Lektsii $i$ eseta ot trideset godini, prev. K. Lozev, Sofia: KALUS i Kosmopolit, ss. 79-96. (Попър, К. (2003а). Логиката на социалните науки, - В: Попър, К. (2003). В търсене на по-добър свят. Лекции и есета от тридесет години, сс. 79-96). [Popper, К. (2003а). The logic of social sciences - In: Popper, K. (2003). In search of a better world. Lectures and essays of thirty years, 79-96)].

Popper, K. (2003b): Popar, K. Kak razbiram filosofiata, - V: Popar, K. (2003). Vtarsene na po-dobar sviat. Lektsii $i$ eseta ot trideset godini, prev. K. Lozev, Sofia: KALUS i Kosmopolit, ss. 190-205. (Попър, К. (2003б). Как разбирам философията, - В: Попър, К. (2003). В търсене на подобър свят. Лекции и есета от тридесет години, сс. 190-205). [Popper, K. (2003b). How I understand philosophy. In: Popper, K. (2003). In search of a better world. Lectures and essays of thirty years, 190-205)].

Popper, K. (2003c): Popar, K. Tolerantnost i intelektualna otgovornost, - V: Popar, K. (2003). V tarsene na po-dobar sviat. Lektsii i eseta ot trideset godini, prev. K. Lozev, Sofia: KALUS i Kosmopolit, ss. 206-222. (Попър, К. (2003в). Толерантност и интелектуална отговорност, - В: Попър, К. (2003). В търсене на по-добър свят. Лекции и есета от тридесет години, сс. 206222. [Popper, K. (2003c). Tolerance and intellectual responsibility - B: Popper, K. (2003). In search of a better world. Lectures and essays of thirty years, 206-222)].

Popper, K. (2003): Popar, K. (2003). V tarsene na po-dobar sviat. Lektsii i eseta ot trideset godini, prev. K. Lozev, Sofia: KALUS i Kosmopolitan. (Попър, К. (2003). В търсене на по-добър свят. Лекции и есета от тридесет години, прев. К. Лозев. С.: КАЛЬС и Космополит). [Рорper, K. (2003). In search of a better world. Lectures and essays of thirty years, transl. by K. Lozev. Sofia: KALAS and "Cosmopolitan")].

Ringer, F. (2004). Max Weber - An intellectual biography. Chicago \& London: The University of Chicago Press.

Weber, M. (2000): Veber, M. (2000). Naukata kato prizvanie, - V: Veber, M. (2000). Ucheniat I politikut, Sofia: EON, ss. 114 - 145. (Вебер, M. (2000). Науката като призвание, - В: Вебер, М. (2000). Ученият и политикът, София: ЕОН, сc. 114-145). [Weber, M. (2000). Science as a Vocation - In: Weber, M. (2000). The scientist and the politician, Sofia: EON, pp. 114-145)]. 
K. Lozev - Scientific Objectivity: How is it Possible?

C O A $\mathbf{s}$ 